\title{
新刊書紹介
}

\section{Migration Ecology of Marine Fishes}

David Hallock Secor 著, Johns Hopkins University Press（2015 年) $/ 17.8 \times 25.4 \mathrm{~cm}, 304$ 頁，US $\$ 99.95$

齢のみならず過去の経験環境や生理状態の痕跡を残す 耳石は, 現在の魚類生態研究に不可欠のツールとなって いる。著者の David H Secor 教授は, 特に耳石微量元 素分析による魚類の回遊研究のパイオニアとして，今な お精力的に学界を牽引する著名な研究者である。本書の 大きな特徵は, 新時代を開いた大御所が解説や総説をを とめるのではなく, 自身の専門をあくまでも魚類生態研 究の一要素と位置づけ, より広範な視点から新たなアイ デアを提示している点だらう。世界的に高名な研究者と いうより，休むことなくサンプルやデータと向き合うア グレッシブな若手の手によるものかと思うほど精力的な 構成である。一方で, 先人の業績を丁寧に解説する著者 の姿勢は, 本書を優れた回遊研究の入門書ともしている。

各章を簡単に紹介すると，まず第 1 章では「Migration とは何か」,「どう捉えられてきたか」について, 古 典から最新情報までを網羅しつつ，その変遷を辿る。こ こだけで，自分の「回遊観」が長い歴史を経て細分化さ れた一部分のみであったことに改めて気づかされた。ま た，用語解説一覧も提示され，この分野に馴染みのない 研究者やビギナーでも容易に入ることができるようにな っている。続く第 2 章では, Migration（回遊, 渡り) の代名詞ともいえる魚類と鳥類について，それぞれ水中 と空中に抢ける移動の物理学的特性や運動様式, ナビ ゲーション, 研究手法などを比較し, Migration の意義 について考察している。以降, 第 3 章は「Mating system and Larval dispersal」, 第 4 章は「Complex life cycle and Marine food webs」, そして第 5 章は「Population structure」と題され, 魚類生態学に打ける重要な テーマについて多くの研究を引用した概説が続く。ここ では数ページにわたり “Migration”という単語すら出 現せず，タイトルを越えた最新の「魚類生態学」のテキ ストを読むようである。しかし，それぞれのべースには 回遊もしくは移動の生態的な必然性と重要性がしっかり と述べられている。第 6 章と第 7 章では, 著者の真骨 頂である多型を含む回遊現象の生態的, 進化的意義につ いて斬新な視点やアイデアが惜しみなく披露される。回 遊に興味を持つ研究者はもちろん, 広く魚類生態学者に 扮勧めしたい一冊である。

（東大大気海洋研 青山 潤）

\section{水族館発！みんなが知りたい釣り魚の生態 釣りのヒントは水族館にあった！?}

海野徹也・馬場宏治 編著, 成山堂書店 (2015 年) / B5 判, 157 頁 2,000 円 + 税

本書の紹介に「全国 21 の水族館から，釣りが大好き で飼育のプロとしての観察眼をもつ 29 人の“アング ラー飼育員”がそれぞれの日常業務のなかでこっそり眺 めた! 実践した! 釣り魚の秘訣を教えます。」とあるよ うに，飼育員の方々が「飼育員の視点」と「釣り人の視 点」から, 渓流から海までの魚釣り（イカ・タコも含む） のヒントを与えてくれます。

釣りをする人ならば，水槽の魚の観察が実際の釣りに 役立つのか？と思ってしまうかもしれません。本書は, その疑問に対する回答から始まり，29の内容と 13 のコ ラム, 著者らと著者らの所属する水族館の紹介で構成さ れています。

魚を釣るためには，䬣を使った釣りでも，疑似饂（ル アーやフライ）を使った釣りでも，魚にそれらを口にく わえて（イカやタコなら，手に取って）貪わなくてはな りません。(友釣りのアユは除外。) つまり「捕食させる こと」が最重要になります。そして慨を食べさせること は, 水族館で展示を続けるためにも不可欠なことです。 本書ではこの捕食について, 飼育員が魚に慨を食べさせ る過程で分かった好みの餌, 食べるタイミング, 食べ 方，そして食べる場所まで詳しく解説されています。ぞ うやったら䬣を食べてくれるのか? や魚種ごとの捕食久 イッチの入り方，そしてその時の魚体の変化など, 釣り 好きな飼育員ならではの観察眼によって得られた知見を あますことなく紹介されています。そして䭒を使う釣り に重要なのは二オイと味です。どのような飭が好まれる のか? についても, 実験や科学的な解説があります。疑 似飭を使う釣りでは，色の選択が気になるところです が，それについても紹介されています。本書を読むと， 魚を知ることが釣果を上げるための近道であることを再 認識させられます。

本書は釣りをしなくても魚の飼育や水族館に興味があ る方ならば，魚の生態の知識を楽しく学べる内容になっ ています。また，本書を読んだ後に水族館を訪れたなら ば, 魚だけでなく, 水槽施設や飼育員に対してもこれま でと違った見方ができるようになっていることと思いま す。

さらに本書は，魚や釣りに関してだけではなく，仕事 と趣味の間で葛藤する飼育員の悲喜交々もうかがい知る ことができる楽しい著書です。釣りをする人はもちろ ん, 釣りをしない人でも楽しく読める一冊です。抢勧め です!

（高知大農 深田陽久） 